\title{
Antibacterial potential of silver nanoparticles against isolated urinary tract infectious bacterial pathogens
}

\author{
Samuel Jacob Inbaneson • Sundaram Ravikumar • \\ Nachiappan Manikandan
}

Received: 14 July 2011/Accepted: 8 September 2011/Published online: 21 September 2011

(c) The Author(s) 2011. This article is published with open access at Springerlink.com

\begin{abstract}
The silver nanoparticles were synthesized by chemical reduction method and the nanoparticles were characterized using ultraviolet-visible (UV-Vis) absorption spectroscopy and X-ray diffraction (XRD) studies. The synthesized silver nanoparticles were investigated to evaluate the antibacterial activity against urinary tract infectious (UTIs) bacterial pathogens. Thirty-two bacteria were isolated from mid urine samples of 25 male and 25 female patients from Thondi, Ramanathapuram District, Tamil Nadu, India and identified by conventional methods. Escherichia coli was predominant (47\%) followed by Pseudomonas aeruginosa (22\%), Klebsiella pneumoniae (19\%), Enterobacter sp. (6\%), Proteus morganii (3\%) and Staphylococcus aureus (3\%). The antibacterial activity of silver nanoparticles was evaluated by disc diffusion assay. $P$. aeruginosa showed maximum sensitivity $(11 \pm$ $0.58 \mathrm{~mm})$ followed by Enterobacter $\mathrm{sp} .(8 \pm 0.49 \mathrm{~mm})$ at a concentration of $20 \mu \mathrm{g} \mathrm{disc}^{-1}$ and the sensitivity was highly comparable with the positive control kanamycin and tetracycline. $K$. pneumoniae, E. coli, P. morganii and $S$. aureus showed no sensitivity against all the tested concentrations of silver nanoparticles. The results provided evidence that, the silver nanoparticles might indeed be the potential sources to treat urinary tract infections caused by P. aeruginosa and Enterobacter sp.
\end{abstract}

S. Jacob Inbaneson $\cdot$ S. Ravikumar $(\bowtie) \cdot$ N. Manikandan Department of Oceanography and Coastal Area Studies, School of Marine Sciences, Alagappa University,

Thondi Campus, Ramanathapuram District, Thondi 623 409, Tamil Nadu, India

e-mail: ravibiotech201321@gmail.com
Keywords Antibacterial sensitivity - Disc diffusion assay · Silver nanoparticles · UTI

\section{Introduction}

Patients with non-infectious diseases who have to stay in hospital for long period such as heart disease, cancer and other chronic diseases have high risk to get nosocomial infections (Nichollas et al. 1975; Asefzadeh 2005; Saonuam et al. 2008). It has been reported that, $10 \%$ hospital patients acquire this infection while staying in hospital (Asefzadeh 2005). The common pathogenic bacteria which include Escherichia coli, Klebsiella pneumoniae, Haemophilus influenza, Streptococcus pneumoniae and Proteus vulgaris are the major causative agents of nosocomial infections (Saonuam et al. 2008; Nichollas et al. 1975). Generally, nosocomial infections develop in respiratory tract (Nichollas et al. 1975) and urinary tract (Saonuam et al. 2008). Treatment with available antibiotics leads to resistance among pathogenic bacteria which leads to greater threat.

In the recent years, silver nanoparticles have been of great interest and widely investigated because of their applications in many areas such as biotechnology (Gao and Xu 2009), microelectronics (Feldheim and Keating 1998), optics (Taton et al. 2000; Zhang et al. 2005) and biomedicine (Caruthers et al. 2007; Farokhzad and Langer 2006; Sahoo et al. 2007; Kumar et al. 2005). It is well known that silver is a very effective antibacterial agent and also possesses a strong activity against bacteria, fungi and viruses, although the mechanism and the manner of action are still not well known (Sharma et al. 2009). Several studies reported that, the silver and silver nanoparticles may attach to the surface of the cell membrane disturbing permeability 
and respiration functions of the cell (Kvitek et al. 2008). It is also possible that silver and silver nanoparticles not only interact with the surface of membrane, but can also penetrate inside the bacteria (Morones et al. 2005). Many researchers also proposed that $\mathrm{Ag}^{+}$ions interact with the thiol groups in bacteria proteins, affecting the replication of DNA (Marini et al. 2007). It has also been reported that $\mathrm{Ag}^{+}$ions uncouple the respiratory chain from oxidative phosphorylation or collapse the proton-motive force across the cytoplasmic membrane (Holt and Bard 2005). The present study was made an attempt to find out the antibacterial activity of silver nanoparticles against the 6 urinary tract infectious (UTIs) bacterial isolates.

\section{Materials and methods}

\section{Preparation of silver nanoparticles}

The silver nanoparticles were prepared by using chemical reduction method (Fang et al. 2005). $50 \mathrm{ml}$ of $1 \times 10^{-3} \mathrm{M}$ $\mathrm{AgNO}_{3}$ was heated to boiling and $5 \mathrm{ml}$ of $1 \%$ tri-sodium citrate was added drop by drop. The solution was mixed vigorously and heated until colour change was evident (pale brown) and stirred until cooled to room temperature. All solutions of reacting materials were prepared in double distilled water. The aqueous solution was air dried up to 3 days so as to enable to obtain powdered form of sliver nanoparticles.

\section{Characterization of synthesized silver nanoparticles}

About $1 \mathrm{ml}$ of solution (diluted with 1:20 v/v Milli Q water) was monitored in UV-VIS spectrophotometer (between 300- and 700-nm ranges with 5-nm intervals) with different time intervals ( $15 \mathrm{~min}, 30 \mathrm{~min}, 4 \mathrm{~h}, 6 \mathrm{~h}$ and $8 \mathrm{~h}$ ). After $8 \mathrm{~h}$ of incubation, the solution was centrifuged with 12,000 rpm for $20 \mathrm{~min}$ and their pellets were re-dispersed in sterile distilled water. The centrifugation and re-dispersion was repeated three times to ensure the complete separation of nanoparticles. The dried mixture of silver nanoparticles was further analysed with X-ray diffractometer (PAN analytical BV, The Netherlands) operated at a voltage of $40 \mathrm{kV}$ and a current of $30 \mathrm{~mA}$ with $\mathrm{Cu}$ $\mathrm{K} \alpha$ radiation in a $\theta-2 \theta$ configuration.

\section{Isolation of UTI bacterial pathogens}

A total of 50 urine samples from 25 male and 25 female patients admitted in the hospitals as UTI problems were collected from different hospitals and laboratory localities along the coastal area of Thondi, Ramanathapuram District, Tamil Nadu, India in a separate sterile wide mouth bottle. Before collecting a sample, the women were instructed to swab the vulvae and men to retract the foreskin and cleanse the glans penis. Mid stream urine was collected in a sterile wide mouthed container. For the isolation of UTI bacterial strains, loop full of urine samples were streaked into the nutrient agar, MacConkey agar, Blood agar and Chocolate agar plates and incubated at $37 \pm 2{ }^{\circ} \mathrm{C}$ for $24 \mathrm{~h}$. Next day individual colonies were selected and identified on the basis of morphological characteristics, gram staining, and biochemical characters (Thomas 1995; Chess Brough 2000).

Antibacterial sensitivity assay

Disc diffusion assay was performed to determine the antibacterial activity in triplicates (Kim et al. 1995). Overnight culture of UTI pathogens were swabbed over the surface of sterile Mueller-Hinton agar plates using sterile cotton swabs. Discs impregnated with different concentrations of silver nanoparticles $(5,10,15$ and $20 \mu \mathrm{g} \mathrm{disc}^{-1}$ ) were applied on the solid agar medium by pressing slightly and incubated at $37 \pm 2^{\circ} \mathrm{C}$ for $24 \mathrm{~h}$ in triplicates. After incubation, the zone of inhibition was measured and expressed as zone of sensitivity millimetre in diameter.

\section{Results}

Out of the 50 midstream urine samples, 32 bacterial isolates were recovered and the biochemical tests revealed that, these isolates belong to 6 species (Table 1). Of these E. coli is the predominant one (47\%); Pseudomonas aeruginosa (22\%), K. pneumonia (19\%), Enterobacter sp. (6\%), Proteus morganii (3\%) and Staphylococcus aureus (3\%) (Fig. 1). The colour intensity of the synthesized silver nanoparticles was increased with increased time duration, and the maximum intensity was observed with 420-nm wavelength (Fig. 2). Further, the results of the X-ray diffraction (XRD) analysis showed $2 \theta$ intense values with various degrees $\left(36.20^{\circ}, 54.56^{\circ}, 63.11^{\circ}\right.$ and $\left.68.72^{\circ}\right)$ and these results correspond to (111), (200), (220) and (311) Bragg's reflection-based (Sathishkumar et al. 2009) silver nanoparticles (Fig. 3). Antibacterial activity of silver nanoparticles is represented in Table 2. The silver nanoparticles showed maximum sensitivity $(11 \pm 0.58 \mathrm{~mm})$ against $P$. aeruginosa followed by Enterobacter sp. $(8 \pm$ $0.49 \mathrm{~mm})$ at $20 \mu \mathrm{g} \mathrm{disc}^{-1}$ concentration. The $P$. aeruginosa and Enterobacter sp. showed sensitivity against all the tested concentrations (5, 10, 15 and $20 \mu \mathrm{g} \mathrm{disc}^{-1}$ ). $K$. pneumoniae, E. coli, P. morganii and S. aureus showed no sensitivity against all the tested concentrations of silver nanoparticles. 
Table 1 Biochemical characterization of isolated bacteria from UTI patients

\begin{tabular}{|c|c|c|c|c|c|c|}
\hline Characteristics & $\begin{array}{l}\text { Pseudomonas } \\
\text { aeruginosa }\end{array}$ & $\begin{array}{l}\text { Escherichia } \\
\text { coli }\end{array}$ & $\begin{array}{l}\text { Klebsiella } \\
\text { pneumoniae }\end{array}$ & $\begin{array}{l}\text { Enterobacter } \\
\text { sp. }\end{array}$ & $\begin{array}{l}\text { Proteus } \\
\text { morganii }\end{array}$ & $\begin{array}{l}\text { Staphylococcus } \\
\text { aureus }\end{array}$ \\
\hline Gram staining & - & - & - & - & - & + \\
\hline \multicolumn{7}{|l|}{ TSI } \\
\hline Slant & K & A & A & A & $\mathrm{K}$ & A \\
\hline Butt & $\mathrm{K}$ & A & A & A & A & A \\
\hline GAS & - & G & G & G & G & - \\
\hline $\mathrm{H}_{2} \mathrm{~S}$ & - & - & - & - & - & - \\
\hline Mannitol & A & A & A & A & - & - \\
\hline Motility & Motile & Motile & Non-motile & Motile & Motile & Motile \\
\hline Indole test & - & - & - & - & + & - \\
\hline Methyl red test & + & + & - & - & + & - \\
\hline V.P. test & - & - & + & + & - & - \\
\hline Citrate test & - & - & + & - & - & - \\
\hline Urease test & + & - & + & - & + & - \\
\hline Oxidase test & + & - & - & - & - & - \\
\hline Catalase test & + & - & - & - & + & + \\
\hline
\end{tabular}

+ Positive, - negative, $K$ alkaline, $A$ acid, $G$ gas

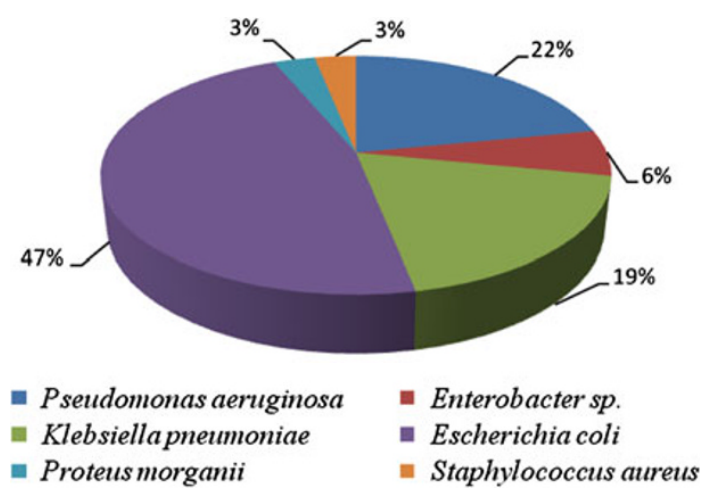

Fig. 1 Percentage occurrence and distribution of bacterial pathogens in UTIs among the patients $(n=32)$

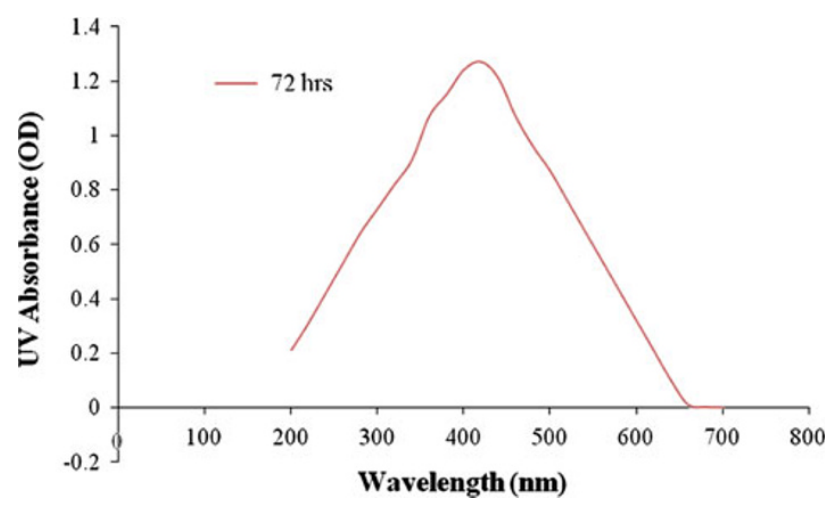

Fig. 2 UV-VIS absorption spectra of the synthesized silver nanoparticles

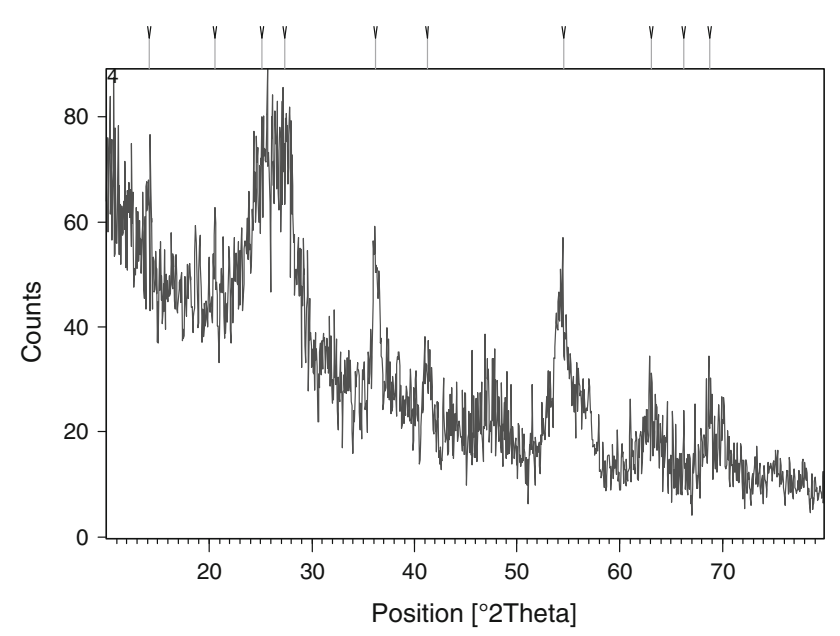

Fig. 3 XRD analysis of the synthesized silver nanoparticles

\section{Discussion}

Patients with non-infectious disease who have stay in hospital have high risk to acquire nosocomial infection. It has been reported that, $10 \%$ hospital patients acquire this infection while staying in hospital (Asefzadeh 2005). Martinez and Baquero (2002) have reported from their research that, nosocomial infectious bacteria exhibited least susceptibility to antibiotics and some of these bacteria out rightly developed multidrug resistance to these antibiotics. Recently from a 3-year follow-up study in USA, Dowzicky and Park (2008) reported that, UTI bacterial 
Table 2 Antimicrobial activity of silver nanoparticles against UTIs pathogens

\begin{tabular}{|c|c|c|c|c|c|c|c|}
\hline \multirow[t]{3}{*}{ Test organism } & \multicolumn{7}{|c|}{ Zone of inhibition (mm) } \\
\hline & \multicolumn{4}{|c|}{ Concentration of silver nanoparticles $\left(\mu \mathrm{g}\right.$ disc $\left.^{-1}\right)$} & \multicolumn{2}{|c|}{ Positive control $\left(20 \mu \mathrm{g} \mathrm{disc}^{-1}\right)$} & \multirow{2}{*}{$\begin{array}{l}\text { Negative control } \\
\text { Sterile distilled wate }\end{array}$} \\
\hline & 5 & 10 & 15 & 20 & Kanamycin & Tetracycline & \\
\hline Pseudomonas aeruginosa $(n=15)$ & $7.0 \pm 0.49$ & $8.0 \pm 0.61$ & $9.0 \pm 0.65$ & $11 \pm 0.58$ & $9 \pm 0.69$ & $7 \pm 0.75$ & - \\
\hline Enterobacter sp. $(n=7)$ & $6.0 \pm 0.37$ & $6.0 \pm 0.52$ & $7.0 \pm 0.58$ & $8 \pm 0.49$ & - & $8 \pm 0.62$ & - \\
\hline Klebsiella pneumoniae $(n=6)$ & - & - & - & - & - & - & - \\
\hline Escherichia coli $(n=2)$ & - & - & - & - & - & - & - \\
\hline Proteus morganii $(n=1)$ & - & - & - & - & - & $7 \pm 0.54$ & - \\
\hline Staphylococcus aureus $(n=1)$ & - & - & - & - & - & - & - \\
\hline
\end{tabular}

$n$ Number of isolates, - no sensitivity, \pm standard deviation

pathogens have exhibited decreased susceptibility rates to tigecycline over the years. Antibacterial property of silver nanoparticles would be the alternative to overcome the resistance problem.

In our present study, E. coli (47\%) was found predominant and a similar result was reported by Ravikumar et al. (2010). Despite the availability of antibiotics, UTIs remain the most common bacterial infections in human populations (Phillippon et al. 1989). Urinary tract infections occur more frequently in females $(63 \%)$ than in males (Schaeffer et al. 2001). Silver is known for its antimicrobial properties and has been used for years in the medical field for antimicrobial applications and even has shown to prevent HIV binding to host cells (Nino-Martinez et al. 2008; Alt et al. 2004; Lee et al. 2007). Additionally, silver has been used in water and air filtration to eliminate microorganisms (Chou et al. 2005).

Previous reports stated that, the silver nanoparticles have potential antibacterial property against E. coli, S. aureus, Staphylococcus epidermis, Leuconostoc mesenteroides, Bacillus subtilis, Klebsiella mobilis and K. pneumonia (Benn and Westerhoff 2008; Chen and Chiang 2008; Falletta et al. 2008; Hernandez-Sierra et al. 2008; Ingle et al. 2008; Jung et al. 2009; Kim 2007; Kim et al. 2007, 2009; Kvitek et al. 2008; Raffi et al. 2008; Ruparelia et al. 2008; Smetana et al. 2008; Sondi and Salopek-Sondi 2004; Vertelov et al. 2008; Yang et al. 2009; Yoon et al. 2008a, b). It has been shown that silver nanoparticles prepared with a variety of synthetic methods have effective antimicrobial activity (Lok et al. 2006; Baker et al. 2005; Aymonier et al. 2002; Melaiye et al. 2005; Sondi and Salopek-Sondi 2004; Kim et al. 2008; Lee et al. 2008; Alt et al. 2004). In the present study, the silver nanoparticles were prepared by chemical reduction method to assess the antibacterial activity. The results of the UVVIS absorption showed increasing colour intensity with increased time intervals and this might be due to the production of the silver nanoparticles and the formation of the brownish yellow colour might be due to the excitation of the surface plasmon vibration of the synthesized silver nanoparticles (Krishnaraj et al. 2010). The result of the XRD pattern indicates the presence of sharp bands of Bragg peaks and this might be due to the stabilizing of the synthesized nanoparticles by chemical reducing agents and thus confirming the crystallization of the bioorganic phase occurs on the surface of the silver nanoparticles (Sathishkumar et al. 2009).

Pseudomonas aeruginosa showed maximum sensitivity $(11 \pm 0.58 \mathrm{~mm})$ at $20 \mu \mathrm{g} \mathrm{disc}{ }^{-1}$ followed by Enterobacter sp. $(8 \pm 0.49 \mathrm{~mm})$. The predominant isolate $E$. coli showed no sensitivity, it might be due to the multidrug resistance nature of $E$. coli developed by point mutations. The mechanism of action may be due to the silver and silver nanoparticles attach to the surface of the cell membrane and disturbing permeability and respiration functions of the cell, moreover, due to the uptake of free silver ions followed by disruption of ATP production and DNA replication. Smaller silver and silver nanoparticles having the large surface area available for interaction would give more bactericidal effect than the larger silver and silver nanoparticles (Kvitek et al. 2008). Normally silver nanoparticles interactions with bacteria are dependent on the size and shape of the nanoparticles (Panacek et al. 2006; Morones et al. 2005; Pal et al. 2007). It is concluded from the present study that, the silver nanoparticles could be used as an effective antibacterial agent for the management of urinary tract infections caused by $P$. aeruginosa and Enterobacter sp. after successful completion of in vivo studies and clinical trials.

Acknowledgments The authors are thankful to the authorities of Alagappa University for providing required facilities and also to Indian Council of Medical Research, New Delhi for financial assistance.

Open Access This article is distributed under the terms of the Creative Commons Attribution License which permits any use, distribution and reproduction in any medium, provided the original author(s) and source are credited. 


\section{References}

Alt V, Bechert T, Steinrucke P, Wagener M, Seidel P, Dingeldein E, Domann E, Schnettler R (2004) An in vitro assessment of the antibacterial properties and cytotoxicity of nanoparticulate silver bone cement. Biomaterials 25:4383-4391

Asefzadeh M (2005) The risk of nosocomial infections for NCD patients. NCD Malays 4:8-12

Aymonier C, Schlotterbeck U, Antonietti L, Zacharias P, Thomann R, Tiller JC, Mecking S (2002) Hybrids of silver nanoparticles with amphiphilic hyperbranched macromolecules exhibiting antimicrobial properties. Chem Commun 24:3018-3019

Baker C, Pradhan A, Pakstis L, Pochan DJ, Shah SI (2005) Synthesis and antibacterial properties of silver nanoparticles. J Nanosci Nanotechnol 5:244-249

Benn T, Westerhoff P (2008) Nanoparticle silver released into water from commercially available sock fabrics. Environ Sci Technol 42:4133-4139. doi:10.1021/es7032718

Caruthers SD, Wickline SA, Lanza GM (2007) Nanotechnological applications in medicine. Curr Opin Biotechnol 18(1):26-30

Chen C, Chiang C (2008) Preparation of cotton fibers with antibacterial silver nanoparticles. Mater Lett 62:3607-3609. doi: 10.1016/j.matlet.2008.04.008

Chess Brough M (2000) Bacterial pathogens. In: District laboratory practice in tropical countries, vol 1. ELBS, London, pp 157-234

Chou WL, Yu DG, Yang MC (2005) The preparation and characterization of silver loading cellulose acetate hollow fibre membrane for water treatment. Polym Adv Technol 16(8):600-607

Dowzicky MJ, Park CH (2008) Update on antimicrobial susceptibility rates among gram - and gram+ organisms in the United sates: results from the tigecycline evaluation and surveillance trial (TEST) 2005-2007. Clin Ther 30:2040-2050

Falletta E, Bonini M, Fratini E, Lo Nostro A, Pesavento G, Becheri A, Lo Nostro P, Canton P, Baglioni P (2008) Clusters of poly(acrylates) and silver nanoparticles: structure and applications for antimicrobial fabrics. J Phys Chem C 112:1175811766. doi: $10.1021 / \mathrm{jp} 8035814$

Fang J, Zhong C, Mu R (2005) The study of deposited silver particulate films by simple method for efficient SERS. Chem Phys Lett 401:271-275

Farokhzad OC, Langer R (2006) Nanomedicine: developing smarter therapeutic and diagnostic modalities. Adv Drug Deliv Rev 58:1456-1459

Feldheim DL, Keating CD (1998) Self-assembly of single-electron transistors and related devices. Chem Soc Rev 27:1

Gao J, Xu B (2009) Applications of nanomaterials inside cells. Nano Today 4(1):37-51

Hernandez-Sierra J, Ruiz F, Pena D, Martinez-Gutierrez F, Martinez A, Guillen A, Tapia-Perez H, Castanon G (2008) The antimicrobial sensitivity of Streptococcus mutants to nanoparticles of silver, zinc oxide, and gold. Nanomed Nanotechnol 4:237-240. doi:10.1016/j.nano.2008.04.005

Holt KB, Bard AJ (2005) Interaction of silver(I) ions with the respiratory chain of Escherichia coli: an electrochemical and scanning electrochemical microscopy study of the antimicrobial mechanism of micromolar Ag+. Biochem 44:13214-13223

Ingle A, Gade A, Pierrat S, Sonnichsen C, Rai M (2008) Mycosynthesis of silver nanoparticles using the fungus Fusarium acuminatum and its activity against some human pathogenic bacteria. Curr Nanosci 4:141-144. doi:10.2174/157341308784 340804

Jung R, Kim Y, Kim H, Jin H (2009) Antimicrobial properties of hydrated cellulose membranes with silver nanoparticles. J Biomater Sci Polym Ed 20:311-324. doi:10.1163/156856209 X412182
Kim J (2007) Antibacterial activity of $\mathrm{Ag}^{+}$ion-containing silver nanoparticles prepared using the alcohol reduction method. J Ind Eng Chem 13:718-722

Kim J, Marshall MR, Wie C (1995) Antibacterial activity of some essential oil components against five food born pathogens. J Agric Food Chem 43:2839-2845

Kim J, Kuk E, Yu K, Kim J, Park S, Lee H, Kim S, Park Y, Park Y, Hwang C, Kim Y, Lee Y, Jeong D, Cho M (2007) Antimicrobial effects of silver nanoparticles. Nanomed Nanotechnol 3:95-101. doi:10.1016/j.nano.2006.12.001

Kim KJ, Sung WS, Moon SK, Choi JS, Kim JG, Lee DG (2008) Antifungal effect of silver nanoparticles on dermatophytes. J Microbiol Biotechnol 18(8):1482-1484

Kim J, Lee J, Kwon S, Jeong S (2009) Preparation of biodegradable polymer/silver nanoparticles composite and its antibacterial efficacy. J Nanosci Nanotechnol 9:1098-1102. doi:10.1166/jnn. 2009.C096

Krishnaraj C, Jagan EG, Rajasekar S, Selvakumar P, Kalaichelvan PT, Mohan N (2010) Synthesis of silver nanoparticles using Acalypha indica leaf extracts and its antibacterial activity against water borne pathogens. Coll Surf B Biointer 76(1):50-56

Kumar CSSR, Hormes J, Leuschner C (2005) Nanofabrication towards biomedical applications, Wiley-VCH Verlag $\mathrm{GmbH} \&$ $\mathrm{Co}, \mathrm{KGaA}$, Weinheim

Kvitek L, Panacek A, Soukupova J, Kolar M, Vecerova R, Prucek R, Holecova M, Zboril R (2008) Effect of surfactants and polymers on stability and antibacterial activity of silver nanoparticles (NPs). J Phys Chem C 112:5825-5834. doi:10.1021/jp711616v

Lee HY, Park HK, Lee YM, Kim K, Park SB (2007) A practical procedure for producing silver nanocoated fabric and its antibacterial evaluation for biomedical applications. Chem Commun 2959-2961. doi:10.1039/B703034G

Lee BU, Yun SH, Ji JH, Bae GN (2008) Inactivation of $S$. epidermidis, B. subtilis, and E. coli bacteria bioaerosols deposited on a filter utilizing airborne silver nanoparticles. J Microbiol Biotechnol 18:176-182

Lok CN, Ho CM, Chen R, He QY, Yu WY, Sun H, Tam PK, Chiu JF, Chen CM (2006) Proteomic analysis of the mode of antibacterial action of silver nanoparticles. J Proteome Res 5:916-924

Marini M, De Niederhausern N, Iseppi R, Bondi M, Sabia C, Toselli M, Pilati F (2007) Antibacterial activity of plastics coated with silver-doped organic-inorganic hybrid coatings prepared by solgel processes. Biomacromolecules 8:1246-1254

Martinez JL, Baquero F (2002) Interactions among strategies associated with bacterial infection: pathogenicity, epidemiology and antibiotic resistance. Clin Microbiol Rev 15:647-679

Melaiye A, Sun Z, Hindi K, Milsted A, Ely D, Reneker DH, Tessier CA, Youngs WJ (2005) Silver(I)-imidazole cyclophane gemdiol complexes encapsulated by electrospun tecophilic nanofibers: formation of nanosilver particles and antimicrobial activity. J Am Chem Soc 127:2285-2291

Morones JR, Elechiguerra JL, Camacho A, Holt K, Kouri JB, Ramırez JT, Yacaman MJ (2005) The bactericidal effect of silver nanoparticles. Nanotechnology 16:2346-2353

Nichollas AC, Pease PE, Gree ID (1975) Agglutinin response to bacterial to bacterial infection in acute exacerbations of chronic bronchitis. J Clin Pathol 28:279-283

Nino-Martinez N, Martinez-Castanon GA, Aragon-Pina A, MartinezGutierrez F, Martinez-Mendoza JR, Ruiz F (2008) Characterization of silver nanoparticles synthesized on titanium dioxide fine particles. Nanotechnol 19(6):065711

Pal S, Tak YK, Song JM (2007) Does the antibacterial activity of silver nanoparticles depend on the shape of the nanoparticle? A study of the Gram-negative bacterium Escherichia coli. Appl Environ Microbiol 73:1712-1720 
Panacek A, Kvitek L, Prucek R, Kolar M, Vecerova R, Pizurova N, Sharma VK, Tat'jana N, Zbořil Z (2006) Silver colloid nanoparticles: synthesis, characterization, and their antibacterial activity. J Phys Chem B 110:16248-16253

Phillippon A, Labia R, Jacoby G (1989) Extended spectrum beta lactamases. J Antimicrob Agents Chemother 33:1131-1136

Raffi M, Hussain F, Bhatti T, Akhter J, Hameed A, Hasan M (2008) Antibacterial characterization of silver nanoparticles against E. coli ATCC-15224. J Mater Sci Technol 24:192-196

Ravikumar S, Gnanadesigan M, Suganthi P, Ramalakshmi A (2010) Antibacterial potential of chosen mangrove plants against isolated urinary tract infectious bacterial pathogens. Int $\mathbf{J}$ Med Med Sci 2(3):94-99

Ruparelia J, Chatteriee A, Duttagupta S, Mukherji S (2008) Strain specificity in antimicrobial activity of silver and copper nanoparticles. Acta Biomater 4:707-716. doi:10.1016/j.actbio.2007. 11.006

Sahoo SK, Parveen S, Panda JJ (2007) The present and future of nanotechnology in human health care. Nanomedicine: nanotechnology. Biol Med 3(1):20-31

Saonuam P, Hiransuthikul N, Suankratay C, Malathum K, Danchaivijitr S (2008) Risk factors for nosocomial infections caused by extended spectrum b-lactamase producing Escherichia coli or Klebsiella pneumoniae in Thailand. Asian Biomed 2:485-491

Sathishkumar M, Sneha K, Won SW, Cho CW, Kim S, Yun YS (2009) Cinnamon zeylanicum bark extract and powder mediated green synthesis of nano-crystalline silver particles and its bactericidal activity. Coll Surf B Biointer 73(2):332-338

Schaeffer AJ, Rajan N, Cao Q, Anderson BE, Pruden DL, Sensibar J, Duncan JL (2001) Host pathogenesis in urinary tract infection. Int J Antimicrob Agents 17:245-251

Sharma VK, Yngard RA, Lin Y (2009) Silver nanoparticles: green synthesis and their antimicrobial activities. Adv Colloid Interface Sci 145(1-2):83-96
Smetana A, Klabunde K, Marchin G, Sorensen C (2008) Biocidal activity of nanocrystalline silver powders and particles. Langmuir 24:7457-7464. doi:10.1021/la800091y

Sondi I, Salopek-Sondi B (2004) Silver nanoparticles as antimicrobial agent: a case study on $E$ coli as a model for Gram-negative bacteria. J Colloid Interface Sci 275:177-182. doi:10.1016/j.jcis. 2004.02.012

Taton TA, Mirkin CA, Letsinger RL (2000) Scanometric DNA array detection with nanoparticle probes. Science 289:1757-1760

Thomas JG (1995) Urinary tract infections. In: Mahon CR, Manuselis $\mathrm{G}$ (eds) Text book of diagnostic microbiology. WB Saunders Co., Philadelphia, pp 949-969

Vertelov G, Krutyakov Y, Efremenkova O, Olenin A, Lisichkin G (2008) A versatile synthesis of highly bactericidal Myramistin ${ }^{\circledR}$ stabilized silver nanoparticles. Nanotechnology 19. doi: 10.1088/0957-4484/19/35/355707

Yang W, Shen C, Ji Q, An H, Wang J, Liu Q, Zhang Z (2009) Food storage material silver nanoparticles interfere with DNA replication fidelity and bind with DNA. Nanotechnology 20. doi: 10.1088/0957-4484/20/8/085102

Yoon K, Byeon J, Park C, Hwang J (2008a) Antimicrobial effect of silver particles on bacterial contamination of activated carbon fibers. Environ Sci Technol 42:1251-1255. doi:10.1021/es07 20199

Yoon K, Byeon J, Park J, Ji J, Bae G, Hwang J (2008b) Antimicrobial characteristics of silver aerosol nanoparticles against Bacillus subtilis bioaerosols. Environ Eng Sci 25:289-293. doi:10.1089/ ees. 2007.0003

Zhang J, Malicka J, Gryczynski I, Lakowicz JR (2005) Metalenhanced fluoroimmunoassay on a silver film by vapor deposition. J Phys Chem B 109:7969-7975 